\title{
Effects of growth-inhibitory concentrations of copper on alginate biosynthesis in highly mucoid Pseudomonas aeruginosa
}

\author{
Jorge H. Leitão and Isabel Sá-Correia
}

Laboratório de Engenharia Bioquímica, Centro de Engenharia Biológica e Química, Instituto Superior Técnico, Av. Rovisco Pais, 1096 Lisboa Codex, Portugal
Author for correspondence: Isabel Sá-Correia. Tel: +351 18417682 . Fax: +35118480072. e-mail : qisc@beta.ist.utl.pt

\begin{abstract}
Alginate production and degree of polymerization were affected when the highly mucoid Pseudomonas aeruginosa $8821 \mathrm{M}$ was grown with growthinhibitory concentrations of $\mathrm{Cu}^{2+}$ (supplied as $\mathrm{CuCl}_{2} ; 1-5 \mathrm{mM}$ ). The inhibition of alginate biosynthesis was consistent with the decreased activity in $\mathrm{Cu}^{2+}$ stressed cells of phosphomannose isomerase/GDP-mannose pyrophosphorylase (encoded by algA), phosphomannomutase (encoded by algC) and GDPmannose dehydrogenase (encoded by algD). However, in cells grown with concentrations of $\mathrm{CuCl}_{2}$ below $2 \mathrm{mM}$, the steady-state $\mathrm{mRNA}$ levels from algA, algC, algD and from the regulatory gene algR1 increased moderately. This observation is consistent with the suggested linkage between the control of alginate gene expression and the global regulation involved in the oxidative stress response. At highly inhibitory concentrations the levels of the four alginate gene transcripts decreased from maximal values. The bell-shaped curves, representing the effect of $\mathrm{Cu}^{2+}$ concentration on mRNA levels from the four alginate genes, exhibited similar patterns but did not concur. The decrease of the specific activity of enzymes necessary for GDP-mannuronic acid synthesis in $\mathrm{Cu}^{2+}$-grown cells was correlated with changes in gene expression, with the inhibitory effect of $\mathrm{Cu}^{2+}$ on enzyme activities and with $\mathrm{Cu}^{2+}$-induced oxidative inactivation of enzymes, especially the particularly sensitive phosphomannose isomerase activity.
\end{abstract}

Keywords: Pseudomonas aeruginosa, copper, alginate biosynthesis, alginate enzymes, alginate gene expression

\section{INTRODUCTION}

The regulation of alginate synthesis in Pseudomonas aeruginosa has been intensively studied because mucoid strains chronically colonize the lungs of cystic fibrosis patients and alginate has been implicated in the persistence of $P$. aeruginosa in the cystic-fibrosis-affected lung (May et al., 1991). Understanding of the molecular basis of alginate synthesis has made this an extremely useful model for the biosynthesis of exopolysaccharides of industrial or ecological significance in Gram-negative bacteria. Environmental and physiological factors such as the concentration of cations (Martins et al., 1990) and of dissolved oxygen in the growth medium (Leitão \& SáCorreia, 1993), the growth temperature (Leitão et al.,

Abbreviations: GMD, GDP-mannose dehydrogenase; GMP, GDPmannose pyrophosphorylase; PMI, phosphomannose isomerase; PMM, phosphomannomutase.
1992) and the phase of growth (Leitão \& Sá-Correia, 1995) modulate the yield and rheological properties of the alginate synthesized by the highly mucoid strain $P$. aeruginosa 8821M (Alves et al., 1991). Under nonstressing conditions, the level of alginate produced has been correlated with the activities of the four enzymes necessary for the formation of GDP-mannuronic acid, the activated precursor for alginate polymerization (Leitão et al., 1992; Leitão \& Sá-Correia, 1995). In addition, during batch growth, the pattern of variation of activity of these alginate enzymes correlated with the co-ordinate transcriptional regulation of the three structural genes which in turn correlated with that of the regulatory $\operatorname{algR} 1$ (algR) gene (Leitão \& Sá-Correia, 1995). The three alginate structural genes are $\operatorname{alg} A$, encoding a bifunctional protein with phosphomannose isomerase (PMI) and GDP-mannose pyrophosphorylase (GMP) activities (Sá-Correia et al., 1987), algC, encoding phosphomannomutase (PMM) (Zielinski et al., 1991) 
and algD, encoding GDP-mannose dehydrogenase (GMD) (Deretic et al., 1987; May \& Chakrabarty, 1994). The regulatory AlgR1 protein mediates the activation of both algC and algD promoters in mucoid strains and in response to high concentrations of salt (Berry et al., 1989; Deretic et al., 1987; Fujiwara et al., 1993). Prolonged stress conditions are thought to trigger a genetic switch to mucoidy that is accompanied by the activation of (at least) algC and algD gene transcription (Deretic et al., 1994; May \& Chakrabarty, 1994). The regulation of alginate biosynthesis in $P$. aeruginosa is complex, involving a hierarchy of several genes (Deretic et al., 1994; DeVries \& Ohman, 1994; May \& Chakrabarty, 1994). At the top of the hierarchy are algU (algT), mucA (algS) and mucB (algN). The mucA and $m u c B$ genes have a negative effect on alginate biosynthesis while the $A \lg U(A \lg T)$ protein is required for transcription of the response regulator genes algB and algR1 ( $\operatorname{algR}$ ) necessary for algD expression. AlgU also directly activates the algD promoter and the promoter of its own structural gene (Wozniak \& Ohman, 1994; DeVries \& Ohman, 1994; Deretic et al., 1994; May \& Chakrabarty, 1994; Yu et al., 1995). Recent evidence indicates that algU encodes an alternative $\sigma$ factor participating in the global stress response in bacteria (Martin et al., 1994; Yu et al., 1995).

Depending on concentration, copper, which is a cofactor in a variety of enzymes, can cause extensive damage in bacteria, leading to growth inhibition and loss of cell viability. Copper readily reacts with the superoxide anion and with hydrogen peroxide via a Fenton-like reaction to generate the highly reactive hydroxyl radical (Halliwell \& Gutteridge, 1989; Storz et al., 1990). Oxygen free radicals are generated as intermediates during the reduction of oxygen to water during normal cellular respiration. These reactive oxygen species lead to the oxidation of sugars, amino acids, phospholipids and nucleic acids with deleterious results (Halliwell \& Gutteridge, 1989). Bacterial defence against, and adaptation to oxidative stress require the induction of the synthesis of a sub-set of proteins and therefore the activation of transcription of the structural genes. Many of these proteins act either by destroying oxidants or by repairing the resulting damage (Storz et al., 1990). Cations are known to influence exopolysaccharide synthesis both qualitatively (chemical composition and properties) and quantitatively (Appanna \& Preston, 1987; Martins et al., 1990; Sutherland, 1990; Kidambi $e t$ al., 1995). For example, the synthesis of the anionic exopolysaccharide alginate is stimulated by $\mathrm{Mg}^{2+}, \mathrm{Mn}^{2+}$ and $\mathrm{Ca}^{2+}$ in P. aeruginosa (Martins et al., 1990) and by $\mathrm{Cu}^{2+}$ in a subset of $P$. syringae strains (Kidambi et al., 1995).

In this study we investigated the effect of growthinhibitory concentrations of $\mathrm{Cu}^{2+}$ on the level of transcription of alg $A, \operatorname{alg} C, \operatorname{alg} D$ and algR 1 in the highly mucoid $P$. aeruginosa 8821M (Alves et al., 1991). This study was undertaken because a linkage between the control of alginate biosynthesis and the global regulation involved in oxidative stress responses in bacteria has been suggested recently (Deretic et al., 1994; Yu et al., 1995). The effects of $\mathrm{Cu}^{2+}$ on the activities of the four enzymes necessary for the synthesis of the alginate precursor GDP-mannuronic acid, on alginate synthesis and on the rheological properties of the product were also analysed. Although the concentrations of $\mathrm{Cu}^{2+}$ examined are not characteristic of the lung environment, this analysis gives some insight into the complexity of alginate regulation. It also gives some clues to the understanding of the effect of toxic metals in the biosynthesis of exopolysaccharides of ecological significance in polluted environments by Gram-negative bacteria.

\section{METHODS}

Bacterial strains, plasmids and culture conditions. The high alginate-producing $P$. aeruginosa strain $8821 \mathrm{M}$ (Alves et al., 1991), which exhibits high levels of the four alginate biosynthetic enzymes and high levels of transcription of their structural genes $\operatorname{alg} A$, alg $C$ and $\operatorname{alg} D$, and of the regulatory gene algR1, was used. Recombinant plasmids pAD4038 (containing the algA gene; Sá-Correia et al., 1987), pNZ49 (containing the algC gene; Zielinski et al., 1991), pVD211 (containing the algD gene; Deretic et al., 1987) and pVDRtac5 (containing the algR1 gene; Deretic \& Konyescni, 1989), hosted in Escherichia coli HB101, were used to prepare the probes for Northern blot analysis. Bacterial growth was carried out at $30^{\circ} \mathrm{C}$ with orbital agitation ( 250 r.p.m.) in $100 \mathrm{ml}$ growth medium contained in $250 \mathrm{ml}$ shake flasks (initial $\mathrm{OD}_{640}=0.3 \pm 0.02$ ). Growth medium was Lennox Broth (Sigma) plus $1 \%$ (w/v) glucose and $\mathrm{MnCl}_{2}$ and $\mathrm{MgCl}_{2}$ (0.5 mM each) (Martins et al., 1990). Growth medium was supplemented with $\mathrm{CuCl}_{2}$ (final concentrations ranging from 0 to $5 \mathrm{mM}$ ). Liquid inocula were prepared in growth medium without $\mathrm{CuCl}_{2}$ supplementation as described elsewhere (Leitão et al., 1992).

Effects of $\mathrm{Cu}^{2+}$ on $\mathrm{P}$. aeruginosa $8821 \mathrm{M}$ growth and alginate production and properties. Growth in the absence or presence of $\mathrm{Cu}^{2+}$ supplementation was monitored by measuring culture $\mathrm{OD}_{640}$. The specific growth rates of $P$. aeruginosa $8821 \mathrm{M}$ in media with or without $\mathrm{Cu}^{2+}$ supplementation were calculated by least-square fitting to the linear part of semi-log growth plots from at least two independent cultures with the same concentration of $\mathrm{CuCl}_{2}$. Results are given as median values of at least two different cultures grown at each $\mathrm{CuCl}_{2}$ concentration.

Alginate concentration was determined after ethanol precipitation from cell-free supernatants by the modified carbazole method (Knutson \& Jeanes, 1968) using sodium alginate from Laminaria byperborea (BDH) as standard. Results are given as median values of three independent analyses of the alginate produced during at least two independent batch cultivations carried out with the same level of $\mathrm{Cu}^{2+}$ supplementation. The viscosity of aqueous solutions $\left(3 \mathrm{~g} \mathrm{l}^{-1}\right)$ of the alginates isolated from cultures during early stationary phase (less than $5 \mathrm{~h}$ after entering the stationary phase) of growth, carried out in the absence or presence of $\mathrm{Cu}^{2+}$, was measured at $30^{\circ} \mathrm{C}$ using a cone and plate Brookfield Viscometer, model LVIIT, at a shear rate of $12 \mathrm{~s}^{-1}$. Results are given as median values of three determinations using at least two independently prepared alginate solutions.

Northern blot analysis. Total RNA was extracted from cells of $P$. aeruginosa $8821 \mathrm{M}$ grown in the presence of increasing 
concentrations of $\mathrm{CuCl}_{2}$ and harvested when the culture $\mathrm{OD}_{640}$ reached the standardized value 1.00 $\pm 0 \cdot 05$. Cell pellets obtained by centrifugation of two independent cultures at the various concentrations of $\mathrm{Cu}^{2+}$ were immediately frozen in liquid nitrogen and processed using the method described by Schmitt et al. (1990). Samples containing $10 \mu \mathrm{g}$ total RNA (estimated spectrophotometrically at $260 \mathrm{~nm}$ ) were loaded in a $1.5 \%(\mathrm{w} / \mathrm{v})$ agarose (FMC)/formaldehyde (Merck) denaturing gel and separated by electrophoresis at $2 \mathrm{~V} \mathrm{~cm}^{-1}$ (Sambrook et al., 1989). The 16S and 23S rRNA bands were visualized after ethidium bromide staining to confirm that equal amounts of RNA had been loaded in each lane. The gels were blotted onto nylon membranes and the RNA was fixed by UV cross-linking (Sambrook et al., 1989). Prehybridization, preparation of the radiolabelled specific probes for $\operatorname{alg} A, \operatorname{algC}$, alg $D$ or algR 1 hybridization experiments, autoradiography and densitometric analysis of the hybridization signals were carried out as described previously (Leitão \& Sá-Correia, 1995). Densitometric results are given as the sum of the intensities of the hybridization bands of the various transcripts corresponding to a specific gene, whenever they were detected, and are means \pm SD of at least three independent Northern experiments using RNA extracts prepared from cells obtained from two independent cultures at the same $\mathrm{CuCl}_{2}$ concentration.

Enzymes assays. PMI, PMM, GMP and GMD activities were assayed in crude cell extracts as described by Martins \& SáCorreia (1991). Crude extracts were prepared (Martins \& SáCorreia, 1991) using cells of $P$. aeruginosa $8821 \mathrm{M}$ grown in media with increasing concentrations of $\mathrm{CuCl}_{2}(0-5 \mathrm{mM})$ and harvested when the culture $\mathrm{OD}_{640}$ reached the standardized value of $1 \cdot 50 \pm 0.05$. The in vitro effect of increasing concentrations of $\mathrm{Cu}^{2+}$ was assessed by the addition of $\mathrm{CuCl}_{2}$ to the enzyme assay mixture (final concentrations in the range $0-40 \mu \mathrm{M})$ and by measuring residual activity after $3 \mathrm{~min}$ incubation. The range of concentrations studied included values that were predicted to be present in the enzyme assay mixtures, prepared with crude extracts from $\mathrm{Cu}^{2+}$-grown cells, based on the $\mathrm{Cu}^{2+}$ concentrations determined in these extracts by atomic absorption spectroscopy. One unit of activity was defined as the amount of enzyme that reduced $1 \mu \mathrm{mol}$ NAD or NADP $\min ^{-1}$ under the assay conditions. Protein concentration in crude cell extracts was in the range $15 \pm 2 \mathrm{~g} \mathrm{l}^{-1}$ and was determined by the method of Bradford (1976) with bovine serum albumin fraction V (Merck) as standard. Specific activities of alginate enzymes are given as the means of at least three enzyme assays and three protein determinations.

Sensitivity of alginate enzymes to oxidative inactivation by the superoxide radical. To compare the sensitivity of alginate enzymes to inactivation induced by the superoxide radical, crude extracts prepared from cells grown in medium without $\mathrm{CuCl}_{2}$ supplementation were incubated at $30^{\circ} \mathrm{C}$ with the xanthine/xanthine oxidase superoxide radical generating system (McCord \& Fridovich, 1969), containing 0.2 U xanthine oxidase (Sigma) and $25 \mu \mathrm{g}$ xanthine (ml extract) ${ }^{-1}$, for up to $35 \mathrm{~min}$ and the residual activity was immediately determined. A control assay lacking xanthine/xanthine oxidase was carried out and it was confirmed that the four enzyme activities maintained initial activities. Results are presented as means \pm SD of at least three enzyme assays.

Determination of $\mathrm{Cu}^{2+}$ concentration in crude extracts. The concentration of $\mathrm{Cu}^{2+}$ in crude extracts prepared, as for the enzyme assays, from cells of $P$. aeruginosa $8821 \mathrm{M}$ grown with increasing concentrations of $\mathrm{CuCl}_{2}$ was determined by atomic absorption spectroscopy at the Laboratório de Análises,
Instituto Superior Técnico, Lisbon, Portugal. Each value is given as the mean $\pm S D$ of the results of two determinations carried out in two independently prepared cell extracts from cells obtained from two independent cultures in medium with the same level of $\mathrm{CuCl}_{2}$ supplementation.

\section{RESULTS} Effect of $\mathrm{Cu}^{2+}$ on $P$. aeruginosa $8821 \mathrm{M}$ growth and on
alginate production and properties

Growth medium supplementation with concentrations of $\mathrm{CuCl}_{2}$ between 1 and $5 \mathrm{mM}$ led to a reduction in the growth rate of $P$. aeruginosa $8821 \mathrm{M}$ (Fig. 1a). Growth inhibition was due to the presence of $\mathrm{Cu}^{2+}$ and not to the counterion $\mathrm{Cl}^{-}$. The supply of $\mathrm{Cu}^{2+}$ as $\mathrm{CuSO}_{4}$ had identical effects on growth and the addition of the same concentrations of $\mathrm{MgCl}_{2}, \mathrm{MnCl}_{2}$ or $\mathrm{CaCl}_{2}$ was not inhibitory (Martins et al., 1990).

Alginate production during batch growth decreased with increasing $\mathrm{CuCl}_{2}$ concentration (Fig. 1b). At or above $4.0 \mathrm{mM}$, no alginate production was detectable (Fig. 1b). Since $\mathrm{Cu}^{2+}$ did not significantly modify the final concentration of biomass produced (Fig. 1a), this toxic cation affected alginate biosynthesis. In addition, the molecular mass of the exopolysaccharides synthesized during growth in the presence of increasing

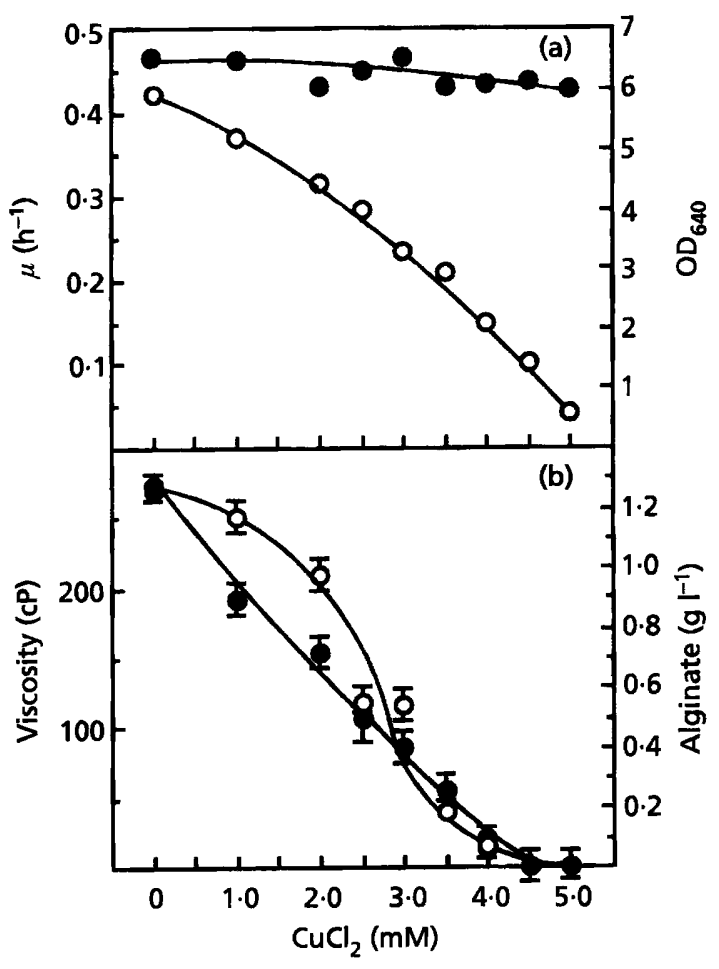

Fig. 1. Effects of the addition of increasing concentrations of $\mathrm{CuCl}_{2}$ to the growth medium of $P$. aeruginosa $8821 \mathrm{M}$ on (a) the specific growth rate $(\mu)(O)$ and the culture $O_{640}$ reached during early stationary phase (O); and $(b)$ the concentration of alginate produced during early stationary phase $(O)$ and the viscosity (centipoise, CP; shear rate $12 \mathrm{~s}^{-1}$ ) of aqueous solutions prepared with these alginates $\left(3 \mathrm{~g} \mathrm{I}^{-1}\right)(0)$. 
(a)

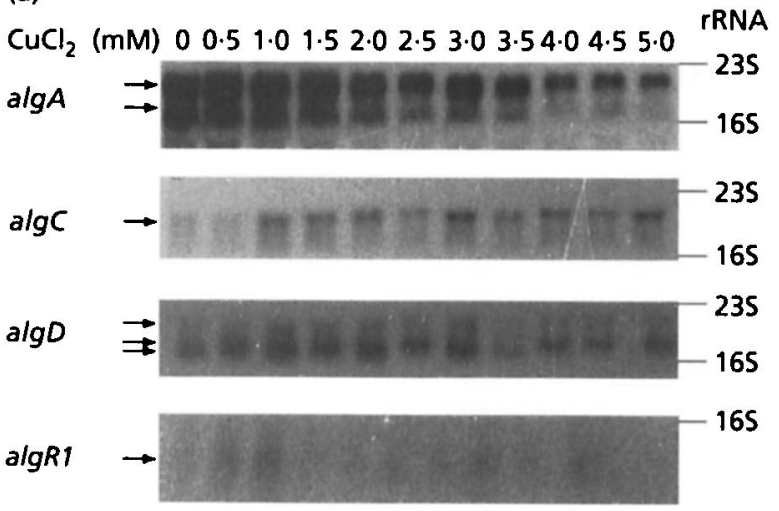

(b)

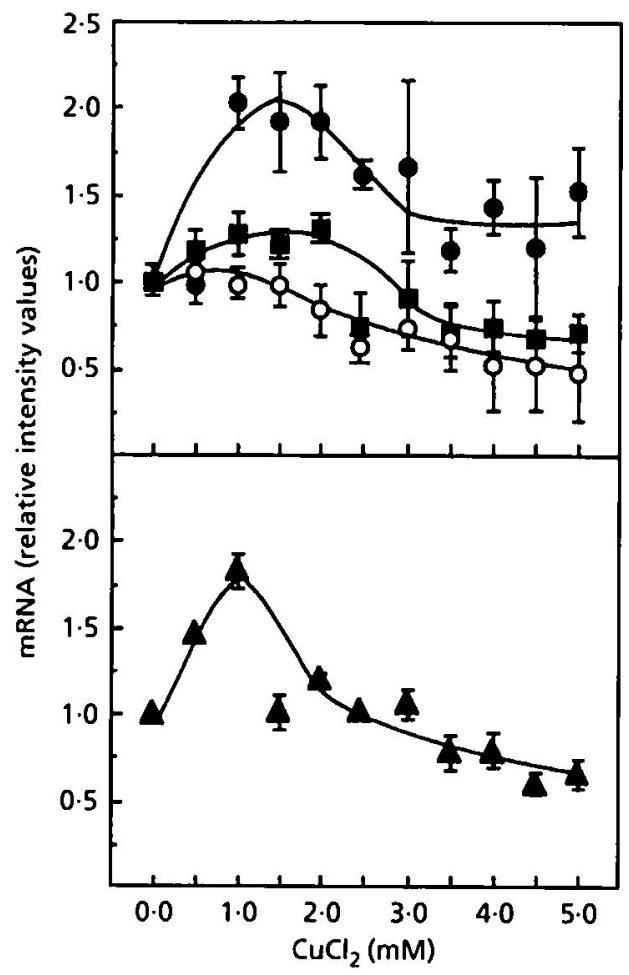

Fig. 2. Effects of the addition of increasing concentrations of $\mathrm{CuCl}_{2}$ to the growth medium of $P$. aeruginosa $8821 \mathrm{M}$ on steadystate levels of mRNA from genes algA (O), algC (O), algD ( and algR1 (A) in cells harvested during late exponential phase. (a) Bands resulting from a representative Northern hybridization analysis ( $10 \mu \mathrm{g}$ total RNA per lane) to alginate genes. (b) Results of the quantification by densitometry of the intensity of the hybridization bands, expressed as relative values; 1.0 being the value for the mRNA of each of the four alginate genes in cells grown in the absence of $\mathrm{Cu}^{2+}$. Values are the sum of the intensities of the hybridization bands (identified by arrows) to the various transcripts corresponding to a specific gene, whenever they were detected, and are means \pm SD of at least three independent Northern blot experiments using RNA extracts prepared from cells obtained from two independent cultures at the same concentration of toxin. Each RNA extract was probed with the four alginate genes but hybridization intensities can only be compared within a blot and not between blots. concentrations of $\mathrm{Cu}^{2+}$ decreased, as suggested by the values of viscosity of aqueous solutions $\left(3 \mathrm{~g} \mathrm{l}^{-1}\right)$ prepared with the isolated alginates. This was confirmed by gel permeation chromatography (data not shown).

\section{$\mathrm{Cu}^{2+}$-dependent transcription of alginate genes}

The effect of $\mathrm{Cu}^{2+}$ on the steady-state mRNA levels from the alginate genes $\operatorname{alg} A, \operatorname{alg} C, \operatorname{alg} D$ and $\operatorname{alg} R 1$ in the highly mucoid $P$. aeruginosa $8821 \mathrm{M}$ was investigated. Confirming previous observations of Chitnis \& Ohman (1993) and Leitão \& Sá-Correia (1995), using nonstressing growth conditions, we were unable to detect a large polycistronic transcript complementary to $\operatorname{alg} A$ and algD (Fig. 2a). Various bands of hybridization to $\operatorname{alg} D$ and $\operatorname{alg} A$ probes (Chitnis \& Ohman, 1993; Leitão \& Sá-Correia, 1995) were observed (Fig. 2a) and exhibited an identical pattern in $\mathrm{Cu}^{2+}$-stressed and unstressed cells (Fig. 2a). Cells used to quantify mRNA levels from the four alginate genes were harvested at the mid-exponential phase of growth, where transcription is maximal (Leitão \& Sá-Correia, 1995). The level of transcripts from algR 1 and from the three structural genes $\operatorname{alg} A, \operatorname{alg} C$ and $\operatorname{alg} D$ reached maximal values in cells grown at concentrations of $\mathrm{CuCl}_{2}$ within the range 1-2 mM (Fig. 2). At higher concentrations, the level of transcripts decreased from maximal levels and, near the maximal concentration for growth, the mRNA from $\operatorname{algR} 1, \operatorname{alg} A$ and $\operatorname{alg} D$ reached values below those in unstressed cells (Fig. 2). The bell-shaped patterns representing the effect of increasing concentrations of $\mathrm{Cu}^{2+}$ on mRNA levels from the transcription of the four alginate genes were, in general, similar, but differed quantitatively. The greatest stimulation by $\mathrm{Cu}^{2+}$ was detected for algC transcription, which was higher than in unstressed cells even in cells grown at the highest $\mathrm{Cu}^{2+}$ concentration that permitted growth (Fig. 2). algA and algD transcription was much less sensitive to $\mathrm{Cu}^{2+}$ than algC or algR1 transcription (Fig. 2).

\section{Activity of alginate enzymes in $\mathrm{Cu}^{2+}$-grown cells}

Although the mRNA levels from algA and algD decreased to values below those in unstressed cells only above $2 \mathrm{mM} \mathrm{Cu}^{2+}$, the activities of the encoded enzymes PMI/GMP ( $\operatorname{alg} A)$ and GMD (algD), assayed in crude extracts, were significantly affected in cells grown at lower concentrations (Fig. 3). Additionally, $\mathrm{Cu}^{2+}$-grown cells also exhibited decreased PMM activity, despite the higher levels of algC transcripts in $\mathrm{Cu}^{2+}$-grown cells as compared with unstressed cells (Figs 2 and 3). Consistent with the patterns of $\mathrm{Cu}^{2+}$-dependent transcription of the three structural genes, the percentage reduction of PMM activity in $\mathrm{Cu}^{2+}$-grown cells was below that of PMI/GMP and GMD activities.

The in vitro effect of $\mathrm{Cu}^{2+}$ on the activity of alginate enzymes was examined by the addition of increasing concentrations of $\mathrm{CuCl}_{2}$ to the enzyme assay mixture using an extract prepared from cells grown with no $\mathrm{Cu}^{2+}$ supplementation (Fig. 4). The concentrations of $\mathrm{CuCl}_{2}$ studied were in the range of those thought to be 


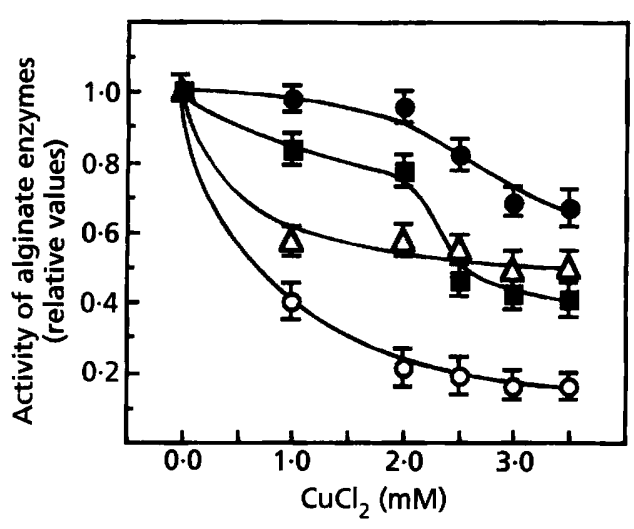

Fig. 3. Specific activity (relative values) of PMI (O), PMM (O), GMP $(\triangle)$ and GMD $(\mathbb{D})$, assayed in crude extracts prepared from cells of $P$. aeruginosa $8821 \mathrm{M}$ grown at $30^{\circ} \mathrm{C}$, in the presence of increasing concentrations of $\mathrm{CuCl}_{2}$ and harvested when the culture reached the standardized $O D_{640}$ of $1.5 \pm 0.05$.

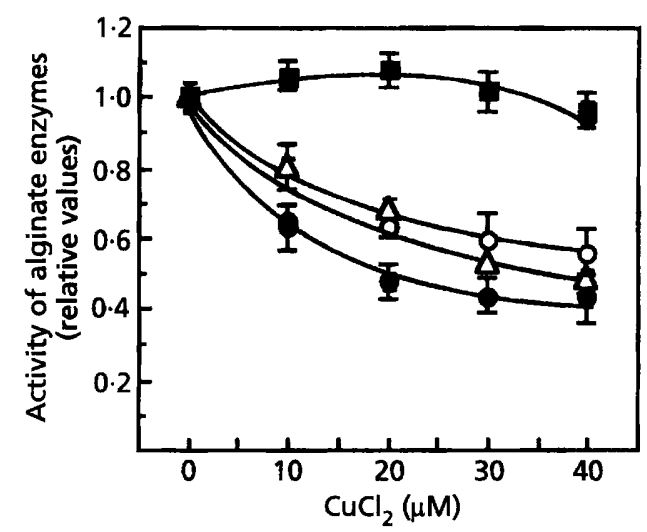

Fig. 4. Residual activity of PMI (O), PMM (O), GMP $(\triangle)$ and GMD ( $\square$ ) in crude extracts, prepared from cells of $P$. aeruginosa $8821 \mathrm{M}$ grown in the absence of $\mathrm{CuCl}_{2}$ supplementation, when increasing concentrations of $\mathrm{CuCl}_{2}$ were added to the enzyme assay mixture.

introduced into the enzyme assay mixtures by the addition of crude extracts prepared from cells grown at different $\mathrm{Cu}^{2+}$ concentrations. The concentrations of $\mathrm{Cu}^{2+}$ present in the various crude extracts were determined by atomic absorption spectrophotometry (Fig. $5)$. In the range of concentrations studied, $\mathrm{Cu}^{2+}$ did not inhibit GMD activity but inhibited, in a similar way, the activities of PMI, PMM and GMP (Fig. 4). Based on these results we have calculated the relative values of the specific activities of the four alginate enzymes that would be assayed in the crude extracts if the inhibitory effect of $\mathrm{Cu}^{2+}$ was eliminated (Fig. 6). Comparing these putative values (Fig. 6) with the steady-state mRNA levels from the structural genes in $\mathrm{Cu}^{2+}$-grown cells (Fig. 2), some discrepancies were found. After discounting the inhibitory effect that $\mathrm{Cu}^{2+}$ has on PMI and GMP, the activity of PMI was much more affected than the activity

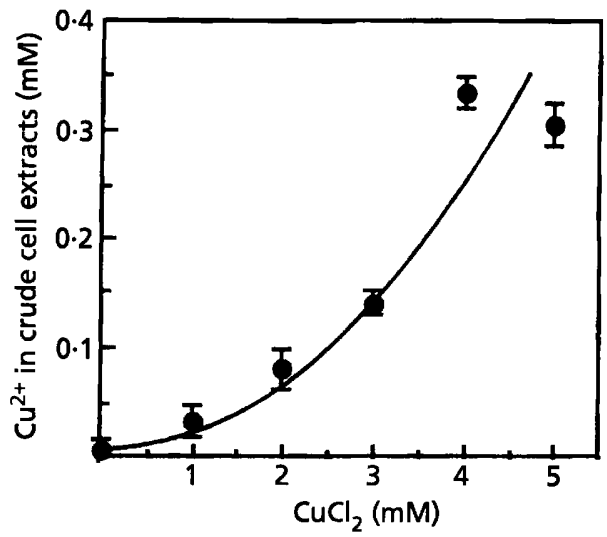

Fig. 5. Concentration of $\mathrm{Cu}^{2+}$ in crude extracts prepared from cells of $P$. aeruginosa $8821 \mathrm{M}$ grown in media supplemented with increasing concentrations of $\mathrm{CuCl}_{2}$. $\mathrm{Cu}^{2+}$ concentration was determined by atomic absorption.

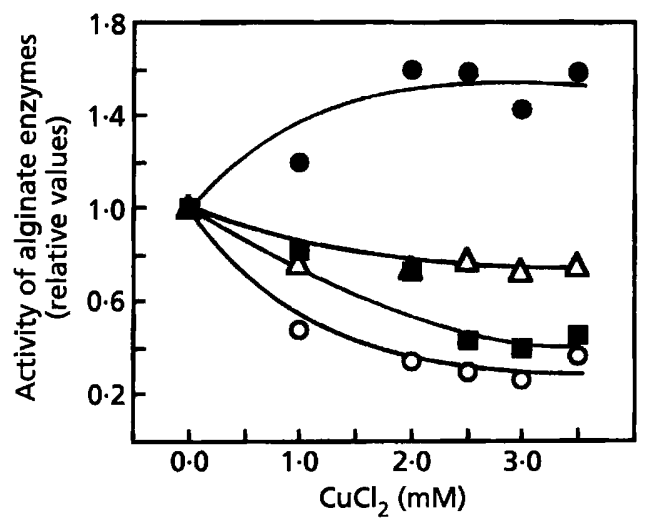

Fig. 6. Specific activities (relative values) of PMI (O), PMM (O), GMP $(\triangle)$ and GMD $(\square)$ that would be present in crude extracts, prepared from $\mathrm{Cu}^{2+}$-grown cells of $P$. aeruginosa $8821 \mathrm{M}$, if the inhibitory effect of the $\mathrm{Cu}^{2+}$ concentrations present in the crude extracts was eliminated. Values were estimated using experimental values in Figs 4 and 5 .

of GMP in $\mathrm{Cu}^{2+}$-stressed cells (Fig. 6). A similar discrepancy was reported previously for cells grown at high concentrations of dissolved oxygen (Leitão \& SáCorreia, 1993), despite PMI and GMP being activities of the same bifunctional protein (Sá-Correia et al., 1987; May et al., 1994). This suggested that an additional mechanism underlies the decrease of the activity of alginate enzymes in cells of $P$. aeruginosa $8821 \mathrm{M}$ grown under $\mathrm{Cu}^{2+}$ stress. We therefore compared the sensitivity of PMI and GMP and the other two enzymes necessary for GDP-mannuronic acid synthesis to oxidative inactivation. This was assessed by incubating a crude extract prepared from cells grown in the absence of $\mathrm{Cu}^{2+}$ with the xanthine/xanthine oxidase superoxide-radicalgenerating system (McCord \& Fridovich, 1969) and comparing the residual activities. The higher sensitivity of PMI to oxidative inactivation as compared with 


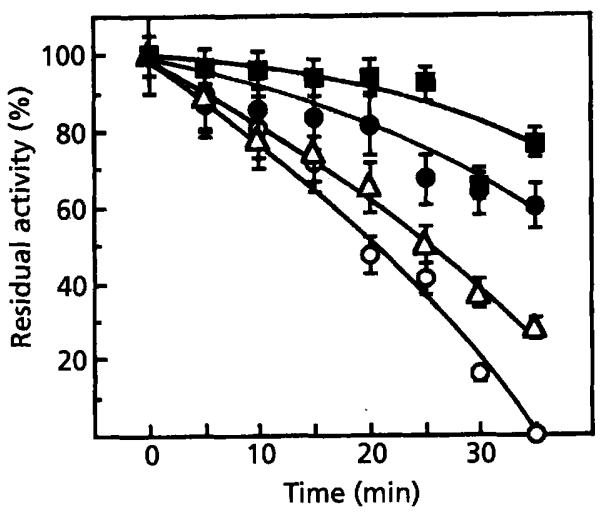

Fig. 7. Residual activities (relative values) of PMI (O), PMM (O), GMP $(\triangle)$ and GMD $(\square)$ in a crude extract prepared from cells of $P$. aeruginosa $8821 \mathrm{M}$ grown in the absence of $\mathrm{Cu}^{2+}$, after incubation at $30^{\circ} \mathrm{C}$ with the xanthine/xanthine oxidase superoxide-radical-generating system for different times up to $35 \mathrm{~min}$.

GMP, previously suggested by its sensitivity to hydrogen peroxide (Leitão \& Sá-Correia, 1993), was confirmed (Fig. 7).

In summary, differences found in the relative specific activities of the four alginate enzymes in crude extracts prepared from cells grown with increasing concentrations of $\mathrm{Cu}^{2+}$ (Fig. 3) are consistent with the level of expression of the structural genes (Fig. 2), if we take into consideration the inhibition of the alginate enzymes by $\mathrm{Cu}^{2+}$ (Fig. 4) and their distinct sensitivity to oxidative inactivation (Fig. 7). The decrease of the activity of all the four enzymes necessary for GDP-mannuronic acid synthesis in cells grown in $\mathrm{CuCl}_{2}$-supplemented medium is also consistent with the decrease of alginate production by $\mathrm{Cu}^{2+}$-stressed cells (Figs 1 and 3).

\section{DISCUSSION}

Environmental stress-inducing conditions such as high osmolarity, presence of ethanol and nutrient (nitrogen source or phosphate) deprivation have been reported to activate the algD and algC promoters (Berry et al., 1989; Fujiwara et al., 1993; May \& Chakrabarty, 1994). In this study we have shown that growth-inhibitory concentrations of $\mathrm{CuCl}_{2}$ below $2 \mathrm{mM}$ also moderately activate the transcription of the alginate structural genes $\operatorname{alg} A, \operatorname{alg} C$ and $\operatorname{alg} D$ and of the regulatory gene algR1. This observation is consistent with the suggested link between the regulation of alginate synthesis and the oxidative stress response in bacteria (Deretic et al., 1994; Yu et al., 1995). The AlgU (AlgT) protein is thought to be a global regulator participating in the oxidative stress response in bacteria and in the activation of some alg promoters (Deretic et al., 1994; Yu et al., 1995). The AlgU (AlgT) protein directly activates the algD and $\operatorname{algR} 1$ promoters as well as its own structural gene promoter. All these promoters display a strong conservation of the -35 and -10 regions and share a high level of similarity with the consensus sequence for promoters transcribed by the $\sigma^{\mathrm{E}}$ RNA polymerase holoenzyme (Martin et al., 1994). It is also expected that $\mathrm{AlgU}$ indirectly activates the transcription of $\operatorname{alg} A$ that is located in the alginate biosynthetic operon controlled from the algD promoter (Chitnis \& Ohman, 1993). Therefore, the up-regulation of alginate structural genes under study by mild copper stress may depend on fluctuations in the concentration of the AlgR 1 protein (also AlgU-dependent) that activates the algC and $\operatorname{alg} D$ promoters (May \& Chakrabarty, 1994) and, indirectly, $\operatorname{alg} A$ transcription. Interestingly, the pattern of $\mathrm{Cu}^{2+}$ dependent transcription of algR 1 showed some similarity to that of the three structural genes, particularly algC. The steady-state mRNA levels from the four alginate genes decreased when the concentration of $\mathrm{CuCl}_{2}$ added to the growth medium was higher than $2 \mathrm{mM}$. The bell-shaped curves representing the effect of $\mathrm{Cu}^{2+}$ on mRNA levels from the four genes, although similar, did not concur. This contrasted with the patterns of their growth-phase-dependent transcription under non-stressing conditions, which were coincident (Leitão \& Sá-Correia, 1995), and may result, at least partially, from the relative sensitivity of the various transcripts to mRNA degradation (Higgins et al., 1993) in $\mathrm{Cu}^{2+}$-stressed and unstressed cells. According to this hypothesis, the $\operatorname{alg} A$ and $\operatorname{alg} D$ transcripts would be the most sensitive. The specific pattern of $\mathrm{Cu}^{2+}$-dependence of the steady-state mRNA level of each one of the four alginate genes might result from several mechanisms participating differently depending on the $\mathrm{Cu}^{2+}$ concentration. As well as the fluctuations in $\mathrm{AlgU}$ ( $\mathrm{Alg} \mathrm{T}$ ) protein concentration, it may be influenced by the level of phosphorylation of AlgR1 (Deretic et al., 1992, 1989; Fujiwara et al., 1993), which appears to be a component of a two-component responsive system (Stock et al., 1989), the energetic state of the cell (Schlictman et al., 1994), and also by fluctuations in the level of other regulatory proteins such as $A \operatorname{lgR} 2$ (AlgQ) and $A \operatorname{lgR} 3$ (AlgP) that also mediate the activation of $\operatorname{alg} C$ and $\operatorname{alg} D$ promoters (Deretic \& Konyescni, 1989; Deretic et al., 1994 ; May \& Chakrabarty, 1994). It is also possible that structural modifications of the various alginate regulatory proteins, due to the action of reactive oxygen species, might additionally affect alginate biosynthesis in the presence of $\mathrm{Cu}^{2+}$.

Despite the higher level of expression of $\operatorname{alg} A, \operatorname{alg} C$ and $\operatorname{alg} D$ in cells grown in medium supplemented with concentrations of $\mathrm{CuCl}_{2}$ below $2 \mathrm{mM}$, the production and degree of polymerization of alginate were significantly affected. The decrease of alginate synthesis at low $\mathrm{CuCl}_{2}$ concentrations is, however, consistent with the decreased activities of alginate enzymes determined in crude extracts from cells grown with concentrations of $\mathrm{CuCl}_{2}$ below and above $2 \mathrm{mM}$. Experimental evidence obtained during this study indicates that the lower activity of alginate enzymes in $\mathrm{Cu}^{2+}$-stressed cells results from the direct inhibitory effect of $\mathrm{Cu}^{2+}$ together with the $\mathrm{Cu}^{2+}$-induced oxidative inactivation of the enzymes, 
especially of the particularly sensitive PMI activity. This last hypothesis is consistent with the distinct level of reduction of PMI and GMP activities in crude extracts of $\mathrm{Cu}^{2+}$-grown cells. These two activities correspond to two independent domains of the AlgA protein and have different sensitivities to hydrogen peroxide (Leitão \& Sá-Correia, 1993) and superoxide anion (this work). The decreased molecular mass of the alginates produced by $\mathrm{Cu}^{2+}$-stressed cells might result from the reduction of their polymerization activity. This could be due to the inhibition of the polymerization enzymes complex by $\mathrm{Cu}^{2+}$ (May et al., 1994) and/or to its oxidative inactivation. In addition, it is also very likely that phospholipid peroxidation by $\mathrm{Cu}^{2+}$-induced oxygen reactive species (Halliwell \& Gutteridge, 1989; Storz et al., 1990) affects lipid-lipid and lipid-protein interactions and, therefore, the activity of membraneembedded polymerization enzymes.

In summary, the up-regulation of alginate gene promoters in cells of mucoid $P$. aeruginosa exposed to mild oxidative stress conditions does not necessarily result in the stimulation of alginate biosynthesis. Cell response might depend upon the deleterious effects of stress on the activity of enzymes involved in the alginate pathway as suggested by results reported in this study. Alginate synthesis in stressed cells is certainly also influenced by the availability of alginate precursors and the energetic state of the cell.

\section{ACKNOWLEDGEMENTS}

This work was supported by JNICT, FEDER and PRAXIS XXI programme (grants: Praxis/2/2.1/BIO/37/94 and 2/2.1/BIO/1125/95) and PhD scholarships BD1216/91-IF and $\mathrm{BD} / 3526 / 94$ to J.H.L. The kind supply of the alg probes by Professor A. M. Chakrabarty (The University of Illinois at Chicago) is gratefully acknowledged.

\section{REFERENCES}

Alves, M. J., Martins, L. O. \& Sá-Correia, I. (1991). Temperature profiles and alginate synthesis in mucoid and non-mucoid variants of Pseudomonas aeruginosa. Lett Appl Microbiol 12, 244-248.

Appanna, V. D. \& Preston, C. M. (1987). Manganese elicits the synthesis of a novel exopolysaccharide in an arctic Rbizobium. FEBS Lett 140, 79-82.

Berry, A., DeVault, J. D. \& Chakrabarty, A. M. (1989). High osmolarity is a signal for enhanced algD transcription in mucoid and nonmucoid Pseudomonas aeruginosa strains. J Bacteriol 171, 2312-2317.

Bradford, M. M. (1976). A rapid and sensitive method for the quantification of microgram quantities of protein utilizing the principle of protein-dye binding. Anal Biochem 72, 248-254.

Chitnis, C. E. \& Ohman, D. E. (1993). Genetic analysis of the alginate biosynthetic gene cluster of Pseudomonas aeruginosa shows evidence of an operonic structure. Mol Microbiol 8, 583-590.

Deretic, V. \& Konyescni, W. M. (1989). Control of mucoidy in Pseudomonas aeruginosa: transcriptional regulation of $\operatorname{algR}$ and identification of the second regulatory gene, algQ. J Bacteriol 171, 3680-3688.
Deretic, V., Gill, J. F. \& Chakrabarty, A. M. (1987). Gene algD, coding for GDP-mannose dehydrogenase is transcriptionally activated in mucoid Pseudomonas aeruginosa. J Bacteriol 169 , 351-358.

Deretic, V., Dikshit, R., Konyescni, W. M., Chakrabarty, A. M. \& Misra, T. K. (1989). The algR gene, which regulates mucoidy in Pseudomonas aeruginosa, belongs to a class of environmentally responsive genes. J Bacteriol 171, 1278-1283.

Deretic, V., Leveau, J. H. J., Mohr, C. D. \& Hibler, N. S. (1992). In vitro phosphorylation of $\mathrm{AlgR}$, a regulator of mucoidy in Pseudomonas aeruginosa, by a histidine protein kinase and effects of small phospho-donor molecules. Mol Microbiol 6, 2761-2767.

Deretic, V., Schurr, M. J., Boucher, J. C. \& Martin, D. W. (1994). Conversion of Pseudomonas aeruginosa to mucoidy in cystic fibrosis : environmental stress and regulation of bacterial virulence by alternative sigma factors. J Bacteriol 176, 2773-2780.

DeVries, C. A. \& Ohman, D. E. (1994). Mucoid-to-nonmucoid conversion in alginate-producing Pseudomonas aeruginosa often results from spontaneous mutations in alg $T$, encoding a putative alternate sigma factor, and shows evidence for autoregulation. $J$ Bacteriol 176, 6677-6687.

Fujiwara, S., Zielinski, N. A. \& Chakrabarty, A. M. (1993). Enhancer-like activity of AlgR1-binding site in alginate gene activation: positional, orientational, and sequence specificity. $J$ Bacteriol 175, 5452-5459.

Halliwell, B. \& Gutteridge, J. M. (1989). Free Radicals in Biology and Medicine, 2nd edn. Oxford: Oxford University Press.

Higgins, C. F., Causton, H. C., Dance, G. S. C. \& Mudd, E. A. (1993). The role of the $3^{\prime}$ end in mRNA stability and decay. In Control of Messenger RNA Stability, pp. 13-30. Edited by J. Belasco \& G. Brawerman. San Diego: Academic Press.

Kidambi, S. P., Sundin, G. W., Palmer, D. A., Chakrabarty, A. M. \& Bender, C. L. (1995). Copper as a signal for alginate synthesis in Pseudomonas syringae pv. syringae. Appl Environ Microbiol 61, 2172-2179.

Knutson, C. A. \& Jeanes, A. (1968). A new modification of the carbazole analysis: application to heteropolysaccharides. Anal Biochem 24, 470-481.

Leitão, J. H. \& SáCorreia, I. (1993). Oxygen-dependent alginate synthesis and enzymes in Pseudomonas aeruginosa. $J \mathrm{Gen}$ Microbiol 139, 441-445.

Leitão, J. H. \& Sá-Correia, I. (1995). Growth-phase-dependent alginate synthesis, activity of biosynthetic enzymes and transcription of alginate genes in Pseudomonas aeruginosa. Arch Microbiol 163, 217-222.

Leitão, J. H., Fialho, A. M. \& Sá-Correia, I. (1992). Effects of growth temperature on alginate synthesis and enzymes in Pseudomonas aeruginosa variants. J Gen Microbiol 138, 605-610.

McCord, J. M. \& Fridovich, I. (1969). Superoxide dismutase: an enzymatic function for erythrocuprein. I Biol Chem 244, 6049-6055.

Martin, D. W., Schurr, M. J., Yu, H. \& Deretic, V. (1994). Analysis of promoters controlled by the putative sigma factor AlgU regulating conversion to mucoidy in Pseudomonas aeruginosa: relationship to $\sigma^{\mathrm{E}}$ and stress response. J Bacteriol 176, 6688-6696.

Martins, L. O. \& Sá-Correia, I. (1991). Alginate biosynthesis in mucoid recombinants of Pseudomonas aeruginosa overproducing GDP-mannose dehydrogenase. Enzyme Microb Technol 13, 385-389.

Martins, L. O., Brito, L. C. \& Sá-Correia, I. (1990). Roles of $\mathrm{Mn}^{2+}$, $\mathrm{Mg}^{2+}$, and $\mathrm{Ca}^{2+}$ on alginate biosynthesis by Pseudomonas aeruginosa. Enzyme Microb Technol 12, 794-799. 
May, T. B. \& Chakrabarty, A. M. (1994). Pseudomonas aeruginosa: genes and enzymes of alginate synthesis. Trends Microbiol 2, 151-157.

May, T. B., Shinabarger, D., Maharaj, R., Kato, J., Chu, L., DeVault, J. D., Roychoudhury, S., Zielinski, N. A., Berry, A., Rothmel, R. K., Misra, T. K. \& Chakrabarty, A. M. (1991). Alginate synthesis by Pseudomonas aeruginosa: a key pathogenic factor in chronic pulmonary infections of cystic fibrosis patients. Clin Microbiol Rev 4, 191-206.

May, T. B., Shinabarger, D., Boyd, A. \& Chakrabarty, A. M. (1994). Identification of amino acid residues involved in the activity of phosphomannose isomerase-guanosine 5 -diphospho-D-mannose pyrophosphorylase: a bifunctional enzyme in the alginate biosynthetic pathway of Pseudomonas aeruginosa. J Biol Chem 269, $4872-4877$.

Sá-Correia, I., Darzins, A., Wang, S.-K., Berry, A. \& Chakrabarty, A. M. (1987). Alginate biosynthetic enzymes in mucoid and nonmucoid Pseudomonas aeruginosa. Overproduction of phosphomannose isomerase, phosphomannomutase and GDP-mannose pyrophosphorylase by overexpression of the phosphomannose isomerase (pmi) gene. J Bacteriol 169, 3224-3231.

Sambrook, J., Fritsch, E. F. \& Maniatis, T. (1989). Molecular Cloning: a Laboratory Manual, 2nd edn. Cold Spring Harbor, NY: Cold Spring Harbor Laboratory.

Schlictman, D., Kavanaugh-Black, A., Shankar, S. \& Chakrabarty, A. M. (1994). Energy metabolism and alginate biosynthesis in Pseudomonas aeruginosa: role of the tricarboxylic acid cycle. $J$ Bacteriol 176, 6023-6029.
Schmitt, M. E., Brown, T. A. \& Trumpower, B. L. (1990). A rapid and simple method for the preparation of RNA from Saccharomyces cerevisiae. Nucleic Acids Res 18, 3091.

Stock, J. B., Ninfa, A. J. \& Stock, A. M. (1989). Protein phosphorylation and the regulation of adaptive responses in bacteria. Microbiol Rev 53, 450-490.

Storz, G., Tartaglia, L. A., Farr, S. B. \& Ames, B. N. (1990). Bacterial defenses against oxidative stress. Trends Genet 6, 363-368.

Sutherland, I. W. (1990). Physiology and industrial production. In Biotechnology of Microbial Exopolysaccharides, pp. 70-88. Edited by J. Baddiley, N. H. Carey, I. J. Higgins \& W. G. Potter. Cambridge: Cambridge University Press.

Wozniak, D. J. \& Ohman, D. E. (1994). Transcriptional analysis of the $P$ seudomonas aeruginosa genes $\operatorname{alg} R$, alg $B$, and $\operatorname{alg} D$ reveals a hierarchy of alginate gene expression which is modulated by algT. J Bacteriol 176, 6007-6014.

Yu, H., Schurr, M. J. \& Deretic, V. (1995). Functional equivalence of Escherichia coli $\sigma^{\mathrm{E}}$ and Pseudomonas aeruginosa AlgU: E. coli ropE restores mucoidy and reduces sensitivity to reactive oxygen intermediates in algU mutants of $P$. aeruginosa. J Bacteriol 177 , 3259-3268.

Zielinski, N. A., Chakrabarty, A. M. \& Berry, A. (1991). Characterization and regulation of the Pseudomonas aeruginosa algC gene encoding phosphomannomutase. J Biol Chem 266, 9754-9763.

Received 17 June 1996; accepted 10 September 1996. 